\title{
Locomotive Engines and the Future of Railway Automotive Power in Africa: A Review
}

\author{
I. I. Ozigis ${ }^{1}$, J. I. O. Oche ${ }^{2}$ and N. M. Lawal ${ }^{3}$ \\ ${ }^{*}, 1,3$ Department of Mechanical Engineering, University of Abuja, NIGERIA \\ ${ }^{2}$ Nigerian Railway Corporation, Ebute Metta, Lagos, NIGERIA.
}

\begin{abstract}
This work presents the review of locomotives and the future of railway automotive power in Africa. Locomotives down time on account of inadequate spare parts still remains a challenge in African. It is thus, imperative to review the locomotives in African, to establish the current capabilities as well as provide recommendations to bridge the gaps and its extrapolated trends in future. Firstly, the comparison factors were track length, electrified rails, number of locomotives and yearly passengers on each of Egypt, Ghana, Kenya, Nigeria, South Africa and Zambia rails. Secondly, the focus was on engine parameters from literatures and maintenance logbooks of locomotives. From available data, it was found that South Africa and Egypt have more advanced rail system than the rest four selected countries. It was also found that additive manufacturing, $3 D$ printing, ductile cast iron and dieforging can be used to produce the engine body for diesel engine using steel and aluminum alloys while aluminum silicon and tin doped with copper are good for reciprocation mechanisms. And finally, increased reliability of locomotives can be guided by an engine selection matrix, while use of renewable and energy hybridization are needed to meet the expansion of railroads in Africa.
\end{abstract}

Keywords: Automotive power, locomotives, manufacturing, renewable energy, train density.

\subsection{INTRODUCTION}

Rail transport is a means to transfer passengers and goods on wheeled vehicles running on rails in which the rolling stocks are guided. In rail transport, rolling stocks (RS) implies all vehicles such as locomotive engines, rail cars, power cars, baggage vans, coaches and wagons on bogies/wheels, that moves on rails [1] The tracks (steel rails, concrete slabs, sleepers, ties and ballast), signaling system, electric wire networks and stations constitute the infrastructure.

Diesel electric locomotive (DEL) consists of diesel engine which drives main generator and in turn provides power for traction motors geared to the wheels. There is no gear box between the diesel engine and the main generator. DEL is the prime mover for train. DEL can be found in front, rear, or as in diesel multiple units (DMU) or in the middle (for multi-heading locomotives). The diesel engine obtains its energy by combustion reaction between atomized fuel and compressed air, and then coverts to mechanical energy via a rotating shaft output. The burning of fuel-air mixture inside the combustion chamber raises the temperature and pressure that slides the piston up and down. The reciprocating effects causes the crankshaft to rotate as the engine output.

The automotive power (AP) in railway system is the source of power for the propulsion of locomotives.

*Corresponding author (Tel: +234 (0) 806298 4934)

Email addresses: idris.ozigi@uniabuja.edu.ng

(I.I. Ozigis), alloys2020@yahoo.com (I.J.O.Oche),

nasir.lawal@uniabuja.edu.ng (N.M. Lawal).
The types available include: the on board prime movers which can be coal, diesel or gas turbine AP. Other types have no on-board prime movers but pantograph linkages whose operations are based on electromagnetic flux. These group include: electric drivers, which can be single or multiple units type and battery powered AP. Both gas turbines and electromagnetic flux AP technologies are not yet in Nigeria. In South Africa and Egypt, electric locomotives (EL) have begun to replace DEL, particularly for commuter lines [2,3]. However, short distances or inter-city travels still use DEL. In Europe, for example, there is coordinated efforts to increase electrified rails in compliance to carbon dioxide $\left(\mathrm{CO}_{2}\right)$ emission reduction policy on global warming [4] .

Manufacturing and availability of diesel electric locomotive parts are still at inadequate level in Africa particularly in Nigeria despite the introduction of rail locomotive transport in the country as early as 1884 , following that of South Africa and India in 1862 and 1853, respectively. Since then, South Africa railways has 22,051 $\mathrm{km}$ rail tracks and India railways has manufactured over 3000 LE via American Locomotive Company (ALCo) [5]. Presently, Nigeria railways corporation (NRC) has over 40 serviceable DEL, some of which, may have been retired, sold as scrapped or undergoing refurbishment. However, NRC with the support of China Civil Engineering Construction Company (CCECC), a subsidiary of China Railway Construction Company (CRCC), has set up her coaches and wagons assembly plant at Kajola, Ogun State, Nigeria but no mentioned of the locomotive engine and/ or engine components 
manufacturing system in place for the production and maintenance of the prime movers and critical parts of the RC. Local LE manufacturing will enhance full refurbishment (replacement for new engine) as well as in partial refurbishment (replacement of new units like: hydraulic, pneumatic, electronic units and control systems). Lack of appropriate engine component contributes to low reliability of LE. The above statement applies to most of the selected Africa countries.

This work is a review of DEL in relation to the future of railway automotive power in Africa. The areas of interest include engine components and DEL parameters to enhance local content in manufacturing and availability of parts for repairs and maintenance. The review of AP is premised on need for enhanced reliability, increased engine output, usage of liquefied and compressed natural gas, introduction of renewable fuels as well as electrification of railway systems.

\subsection{Review of Rail Locomotives in some African Countries}

Rail locomotive performance parameters were used to present rail systems in selected Africa countries in this work. A researcher [6] reported the use of data such as rail network length, locomotive numbers and capacity, number of passengers and number of railway stations for access and egress for the rail locomotive performance. Similarly, a researcher [7] recognized the rail locomotive performance parameters to be infrastructure, economics and technological criteria for assessment of railway systems. The resulting performance indicators will give the train density (overall rail length over national population of a country) [2], travel volume, ridership, seat occupancy, average trip length of passengers, and yearly performance of the individual train sets $[6,8,9]$. The selected Africa countries were Egypt, Ghana, Kenya, Nigeria, South Africa and Zambia. In this work, total length of rail network that consists of main line, narrow and standard lines, shunting, intermodal and connecting lines; the type, number and capacity of locomotives, multiple units and coaches; volume of passengers and cargoes, as well as the presence of electric locomotives, were used to describe each country's railways for purpose of comparative growth.

The Nigeria railway development started in 1884 from Iddo, Lagos and by 1930 the railroad had gotten to Nguru, Yobe State, in the North-Eastern line. Kaura Namoda in Zamfara State and Maiduguri in Borno State were connected to the rail network by 1945 and 1964 respectively in the North-western and North-Eastern lines, respectively $[10,11]$. The total operational rail network is $3667 \mathrm{~km}$ and there is plan to add $8,000 \mathrm{~km}$, with average rail density of $23 \mathrm{~km} /$ million population [2, 11]. This network includes narrow and standard gauges as well as shunting and connecting lines. Train fleet, number of main line locomotives, multiple units, shunting locomotives and rolling stocks have continuously been replaced over the years. NRC have nearly over 200 locomotives of which $75 \%$ are not operational $[11,12]$. There are 54 shunting locomotives as well as 480 and 4900 passenger coaches and freight wagons, of which about $50 \%$ are functional $[11,12]$. Nigeria railways have retired the last fleet of her steam locomotives into museum, but have DEL in her fleet and is yet to have any electric locomotive (EL) as at date. In 2019, NRC established wagon assembly plant in collaboration with CCECC of China at Kajola, Ogun State. In 1964, NRC had 11.3 million passengers and cargo of 3 million metric tons [13, 14]. The number of passengers and freight cargoes have reached over 4 million in the past but in 2019, the number is slightly over 3.5 million of passengers and over 330 , 000 tons of cargo [15].

Ghana Railway's development began in 1901s primarily for mineral transport and military operations. The railway network connects Accra, Kumasi, and Sekondi-Takoradi and is manage by Ghana Railways Corporation (GRC) [16]. The total track network is 947 $\mathrm{km}$, that spread into eastern, central and western lines. About $130 \mathrm{~km}$ is currently operational for passengers and cargo services, while $32 \mathrm{~km}$ double track is not functional as stated in railway master plan (RMP) of Ghana [17]. In the RMP [16], the Government of Ghana, plan to add $4007.6 \mathrm{~km}$ of rail network, mainly $1,067 \mathrm{~mm}$ and 1,435 $\mathrm{mm}$ [17]. A researcher [18] reported periodic procurement of locomotives for the Ghana railways in 2006 such as 61 locomotives and 100 covered wagons with coaches. Furthermore, two DMU were ordered from China in 2008 and commissioned in 2010 [17]. Earlier, 15 locomotives of $1197 \mathrm{~kW}$ capacity and 11 shunting locomotives were ordered for in 1995, prior to those of RMP [17] of 2013. The current cargo per year is about 677000 tons per year down from 28.2 million tons in the past [17]. The yearly Ghanaian rail density is about $40 \mathrm{~km} /$ million population [2]. The RMP [14] of Ghana did not contain immediate and medium plan for EL as its focus, but to rehabilitate and expand rail network and procure more RS [19].

South Africa has extensive rail network that began around 1862. South Africa rail lines are linked with her neighbors and up to Malawi, that facilitates her export based economy [2]. The rail network in South Africa is over $22,051 \mathrm{~km}$ of which $1500 \mathrm{~km}$ is standard and 8200 $\mathrm{km}$ are electrified for electric train [2]. South Africa has over 1064 locomotives which are constantly upgraded, rehabilitated and old ones replaced [20]. South Africa has capacity to manufacture coaches and wagons as well as some diesel locomotives. The rail passengers were reported to be over 237.3 million in 2018 and rail density of $440 \mathrm{~km} / \mathrm{million}$ population and manage by South Africa Railways (SAR), Transnet Freight Rail (TFR) and Spoornet. $[2,20]$.

Egypt railways began operation since 1854 up till date and connects neighboring countries like Algeria and 
Palestine. The track is standard of $1435 \mathrm{~mm}$ with about $4430 \mathrm{~km}$ operational and electrified rails of $55 \mathrm{~km}$ and manage by Egyptian National Railways (ENR). [3]. The rail network connects Suez to Cairo, then to Tanta, Talkha and Zagazig. The Egypt's rail network is expected to reach $10,500 \mathrm{~km}[21]$. The electrify rail network is about $63 \mathrm{~km}$ and connects Cairo and Helwan and Heliopolis [21, 22]. Egypt's DEL is over 821 units but Egypt buys LE and manufacture her coaches and wagons. The passengers and cargos tonnages are 311 million and 1592 million tons, respectively, in 2012 and rail density of about $61 \mathrm{~km} /$ million population $[2,21]$.

Kenya railway corporation was founded in 1977 and its network was constructed to connect cities and neighboring countries such as Uganda and South Sudan [23]. The total length of Kenya's rail network is $2066 \mathrm{~km}$ at narrow guage of $1026 \mathrm{~mm}, 175$ locomotives and 6000 wagons and manage by Rift Valley Railways (RVR) [24]. The Kenya railway's cargos tonnage of 12 million tons in 2020 and had rail passenger of over 2 million in 2018, with a rail density of about $57 \mathrm{~km} /$ million population [2, 25]. China Road and Bridge Corporation (CRBC) is currently involved in the expansion of rail networks in Kenya as well as procuring of more rolling stock. Electrified rail network is not yet in the country [26, 27].

The total rail network of Zambia is about 2164 $\mathrm{km}$. Zambia has about 37 locomotives with 24 operational while 13 defectives in 2014 [28]. Similarly, only 1342 wagons out 2040 wagons were in functional state in 2014 and no electric trains yet [28]. Zambia railway is essentially for freight as about 700,000 tons were moved in 2009 , with rail density of $203 \mathrm{~km}$ per million population and manage by Zambia Railways (ZR) and Railway Systems of Zambia (RSZ) [2, 28].

Comparing the six selected Africa countries railway systems on the same four parameters with India as a reference country, it can be said that India is relatively more advanced. India railways, commenced in 1853, has expanded its rail network to about $66,697 \mathrm{~km}$ and electrified lines to about $23,555 \mathrm{~km}$ as at 2016 [29]. India railways started with three steam locomotives and subsequently acquired 5232 diesel locomotives and 4823 electric locomotives and 30 steam locomotives as at 2014 [5].

Indian railways have capability to assembly locomotives which started with technical collaborations with General Motors of USA, that resulted in establishment of locomotive engine assembly at Varanasi in Uttar Pradesh, India [5]. India railways have increased her local content in LE manufacturing with active research on energy saving technologies $[30,31]$. There are about 1000 wide broad diesel mixed train (WDM) LE with rated power of $1939 \mathrm{~kW}$, working for the Indian Railways, which were upgraded ALCo DEL. The DEL were rebuilt after 18 years of active service, and later upgraded to a higher power rating of $2312 \mathrm{~kW}$ [5]. India railways operates more than 11000 trains per day of which 7000 are the passenger trains. Rail passengers were in excess of 6.5 billion in 2014 [32].

\subsection{Railway Automotive Power}

Steam locomotives powered by steam engine, boilers and cylinders were the forerunners in passengers and cargos rail transport across the world. The trend to replace old, inefficient locomotives with modern and more efficient ones were also observed in the selected African countries. The below description of previous acquisition of locomotives were similar to what took place in Egypt, Ghana, Kenya, Nigeria, South Africa and Zambia rails. The steam locomotives had low efficiency, large labour force and emits large flue gases.

In Nigeria, in 1955, to overcome the demerits associated with steam locomotives and increase the hauling capacity, the steam locomotives were replaced with 10 no of DEL with model English Electric SRKT of $504 \mathrm{~kW}$ output, $89 \mathrm{~km} / \mathrm{h}$, weight of about 53 tons, manufactured by English Electric [33]. These $504 \mathrm{KW}$ locomotives could not haul heavy mineral cargoes across high gradients in Northern Nigeria to ports in the south. In 1958, Electro-Motive Division (EMD) of General Motors (GM), supplied 25 no of DEL of model EMD12$567 \mathrm{C}$ at power rating of $977 \mathrm{~kW}, 81 \mathrm{~km} / \mathrm{h}$ with weight of about 79 tons, to NRC, to overcome the limitations associated with the $504 \mathrm{KW}$ DEL except speed [33]. Eight no of model MA301FAK diesel-electric LE with power output of $872 \mathrm{~kW}$, weight of 66 tons and maximum speed of $81 \mathrm{~km} / \mathrm{h}$ for 1201-1207 class locomotives were acquired in 1962. The merit of additional MA301FAK DEL similar to EMD12-567C were to meet heavy mineral traffic demand. Similarly, another 29 no with power rating of $970 \mathrm{~kW}$, weight of 78 tons and maximum speed of 70 $\mathrm{km} / \mathrm{h}$ of model AEI/Metropolitan Vickers (Sulzer LDA28C), were imported in 1966 by NRC [33]. In 1972, 12 no LE of Hitachi diesel-electric (MAN6V22/30ATL) of $1118 \mathrm{KW}$ with weight of 80 tons and 54 no LE of ALCo $8.251 \mathrm{E}$, rated with weight of 100 tons, both of $1130 \mathrm{~kW}$, were imported for the use of NRC [33]. The addition of ALCo8.251E DEL were specifically bought the eastern line from port Harcourt to Maiduguri, due its stability on gradient with heavy load. 1n 1977, 30 no EMD12-645E, with weight of about 80 tons and $970 \mathrm{~kW}$ were imported into Nigeria. The demerit of ALCo and EMD, include high short hood with visibility limitation. Despite this drawback, EMD LE has been most versatile, among other locomotives into Nigeria. Its presence has led to minimization of down time of LE, as cannibalization becomes easy with same models in a fleet.

Today, most of the above mentioned LE have been scrapped and no longer exist in NRC fleet of locomotives. In some circumstances, the LE on retirement were converted to standby generators to provide electricity as in Nigerian flour mills limited, Apapa, Lagos. However, 1701 class of DEL built by Montreal Locomotive Works (Bombardier Inc) still exist. General 
Electric of USA was the builders of GE-FDL-12$1650 \mathrm{~kW}$, with weight of 92 tons (6 no) and GE-FDL-8$1365 \mathrm{~kW}$ with weight of 82 tons (45no) DEL were imported for Nigeria railways, in 1976 and 1977, respectively. The merits to add GE-FDL-12-1650 KW, were specifically for the eastern line from port Harcourt to Maiduguri, due its stability on gradient with heavy load. In 1992/1993, Nigeria railways imported 15 no. DEL build by ABB Henschell and Hyundai (EMD 12-645E3B) for 1901 and 2001 class locomotives at rating of $1310 \mathrm{~kW}$ and weight of 100 tons each, respectively, to meet the mass transit demand in Lagos in western line. Between 1996-1999, 50 no DEL rated at $2244 \mathrm{KW}$, weight of 90 tons and maximum speed of $120 \mathrm{~km} / \mathrm{h}$, were imported from Dalian Locomotive and rolling Stock works of China via CCECC of China as well as 150 coaches, 400 wagons and 20 rail buses [34]. These Chinese locomotives have problems of frequent failure on wheel slips and component parts not interchangeable even among the same model. In 2010, 25 no GE DEL of model C25EMPD, assembled in Brazil, were imported into Nigeria which were classed as 2200/2300. These Brazilian locomotives were imported to overcome the excessive down time associated with Chinese locomotives. Recently, diesel multiple unit (DMU) locomotives, with potential for upgrade to electro-diesel locomotives, (if right electric infrastructures such as pantograph or overhead wires are in place), were imported to meet traffic demands in Lagos metro, Abuja-Kaduna and Itakpe-Warri routes of NRC, respectively. CCECC with China railway rolling stocks corporate limited, Dalian, (CRRC) has begun to penetrate NRC with respect to type CK6E4 DEL. Nigeria, is yet to acquire EL as already being practiced in Egypt and South Africa [2, 3].

\subsection{BASIC COMPONENTS OF DIESEL LOCOMOTIVE ENGINES. \\ $2.1 \quad$ Engine Block}

Engine block provides the support for the other engine component parts. Cast aluminum cylinder with cast iron liners and piston have prevailed over simple cast process in which the piston runs directly on the alloy bores for diesel engine $[35,36]$. The needs to manufacture engine blocks that achieves fuel consumption reduction in LE has resulted in shift from cast iron to aluminum alloy as aluminum lighter engine block leads to enhanced thermal conductivity and efficiency $[37,38]$. The thermal conductivity arose from low temperature of the crankshaft bearing and inner bore region in the morning on start of the engine and on engine running that can reach up to $150^{\circ} \mathrm{C}$ and $200^{\circ} \mathrm{C}$, respectively, but dissipate its heat into coolant [37].

\subsection{Crankshaft}

Locomotive engines are required to have high output, severe service conditions with solid crankshaft that is small in size $[39,40]$. The severe service conditions include cyclic loading that requires high fatigue strength and wear resistance material such as forged steel crankshaft for DEL. The design of crankshaft normally incorporates dynamic loading, which are optimized to obtain effective shaft diameter and size [39]. Forged carbon steels (with heat treatment) and alloy steels crankshafts are preferred relative to cast iron due to lighter weight, precise dimensions and better damping required in DEL to meet the required high output and cost [40]. Similarly, some researchers [41, 42], investigated forged steel and ductile cast iron crankshaft. The researchers concluded that cast iron crankshaft can be replaced by forged crankshaft from strength point of view. Some researchers [43] reported methods of crankshaft manufacturing that includes forging, casting, machining which are being replaced with modern methods such as 3D printing, rapid prototype and rapid manufacture to produce locomotive engine crankshaft. The common failures in the crankshaft are at the centre of cranks due to twisting and at the two ends. Some researchers [44] conducted failure analysis on V12 DEL crankshaft used in trains, with verdict that the crack initiation was from web fillet of the crankshaft.

\subsection{Bearings}

Some researchers [45] examined 616 crankshaft bearings damaged by different mechanisms and fault tree analysis was performed. The researchers concluded that most causes of failures are abrasive, adhesive and surface fatigue wear. The causes of failures are then incorporated in material selection for the locomotive crankshaft bearings as well as for wheel and differential bearings [46]. Locomotive crankshaft bearing can be made from aluminum tin copper alloy (850 alloys), which has excellent compressive properties and unique lubricating properties under over-heat conditions. Copper additions influence the solidification process and promote coarser tiny particles. If normal lubrication fails with overheating of a journal bearing, the tin melts at $231^{\circ} \mathrm{C}$ and exudes from the over-heated surface to provide emergency liquidtin lubrication and prevents catastrophic failure such as fatigue defects, wear and seizure [46]. Some researchers $[47,48]$ worked on behaviour of engine main bearing under dynamic load with influence of oil film, crankshaft and engine block. The researchers conclude that the right fluid is one with lubrication properties such as orbit movement and oil film thickness that can improve bearing performance.

\subsection{Connecting Rod}

A connecting rod rotates at both ends that results in instantaneous angular displacement between the connecting rod axis and the piston axis as the piston slides up and down the cylinder. There are several factors that guide the selection and manufacturing of connecting rod 
among which are type of power output of the engine, weight, cross sectional configuration, speed range, rpm, material and heat treatment that collectively leads to high performance expected in DEL [49]. Some researchers [50] worked on design consideration for connecting rod based on materials selection. The researchers concluded that Ti$6 \mathrm{Al}-4 \mathrm{~V}$ had the highest factor of safety than other materials for the same loading conditions in the manufacturing of connecting rod. Some researchers [50, 51] worked on design, simulation and manufacturing of connecting rod from ultrafine grained material and isothermal forging. The severe plastic deformation process resulted in increase of $20 \%$ in the hardness. The other production processes for connecting rods include die forging and powder metallurgy for the forged steel and carbon steel alloys. Connecting rod failures include throwing and rod bearing breakages.

\subsection{Piston}

The main purpose of piston in an engine is to transfer force from expanding gas in the cylinder to the crankshaft. The effects of this, can cause fatigue damage of piston in the form of piston side wear and piston head cracks [52]. Some researchers [53] worked on design and analysis of piston using different materials such as A2618, Al-GHS1300 and Ti6Al4V using operating parameters of specified gas pressure, temperature and material properties. The duo concluded that Al-GHS1300 aluminum alloy is the best for piston of Bajaj pulsar 220cc on account of least deformation and weight. Production of piston using 3D printing is among recent advances in addition to additive manufacturing [54]. The mechanical loads on the piston result from peak pressures up to 200 bar in the combustion chamber and forces of inertia caused by high acceleration due to the reciprocating motion of pistons [55]. The thermal loads on the piston has gas temperature between 1800 and $2600^{\circ} \mathrm{C}$ and exhaust gas temperature between 500 and $800^{\circ} \mathrm{C}$ [55]. Therefore, a piston should have enormous strength, minimum mass and be able to dispense the heat of combustion quickly. Piston can be produced by gravity die casting with controlled solidification or forged with reduced wall thickness. Some researchers [54] stated that there is increase in use of alloyed steel piston instead of aluminum due to higher power requirements of LE, particularly for increased higher effective pressure that leads to improved thermal efficiency, However, lubrication condition of alloyed steel piston is inferior to aluminum alloy piston. A researcher $[56,57]$ reviewed advances in piston rings with focus on interaction between ring-cylinder wall interface, that can result in severe friction, wear, oil consumption and power loss in LE.

\subsection{Cylinder Head}

Cylinder heads are made from aluminum alloys that contains silicon, magnesium, and small quantity of copper. The added alloys on the aluminum is to give high strength and weight reduction as well as good thermal conductivity, good casting properties and machinability $[58,59]$. Many cylinder heads are nowadays produced by die casting as well as lost foam casting process [59]. The cylinder head, provides a sealed cap for the combustion chamber as well as holding the plugs and the valve mechanisms in place. Dry sleeves do not contact the liquid in the water jacket, while the wet sleeve is part of the water jacket. The combustion chamber size varies from a minimum when the piston is at top dead centre (TDC) to a maximum when the piston is at the bottom dead centre (BDC) [56]. Cylinder head must be strong and rigid to withstand fluid dynamics acting through the engine block as well as to meet increasing combustion pressure expected to reach 200 bar in diesel engine [56]. Cylinder head can be produced by gravity die casting using aluminum silicon and copper alloys due to advantages of light weight and high thermal conductivity as well as to meet strength requirement at $250^{\circ} \mathrm{C}$, thermal loads and fatigue cycles [60]. Some researchers [60] reported advances on automotive cylinder heads with focus on effect of thermal and mechanical loading using constitutive models that incorporates environment and fatigue. They stated that the models voided the use of simple assumption and over average in design of aluminum alloy cylinder head for automotive engines.

\subsection{Rocker Arm and Camshaft}

The rocker arm is part of the valve actuating mechanism and is responsible for oscillating the lever for conveyance of radial movement from the cam lobe into linear movement as the push rods opens the valves [61]. The process of rocker arm opening and closing of the intake and exhaust valves leads to admission of fuel and air into combustion chamber during the intake stroke or exhaust gases to be expelled during the exhaust stroke [62]. Weight and strength of rocker arm are important, hence forged carbon steel is used in its manufacture, to meet energy required for the low rotation, higher torque and durability in diesel locomotive engine. Failure fracture often occurs at hole of the rocker arm, which can start from multiple origins such as corrosion, wear, friction and bending load. However, some researchers [63] reported the design and development of a 2-step rocker arm. The researchers developed a prototype to validate the rocker arm based on slider design. Camshafts can be made of forged steel, cast iron and hollow shaft with cam lobes press-fitted. A group of researchers [64] worked on design and manufacturing of camshaft. The researchers illustrated the applications of models such as 3D model and software Pro engineer that led to generation of programs for computer numerical control machine (CNC).

\subsection{Exhaust manifold}

Exhaust manifold system consist of the pipeline that carries exhaust gases away from the exhaust valves 
on cylinder heads, it also includes the catalytic converter to reduce emissions, muffler to reduce noise and into a tailpipe to carry flue gases to the surrounding [65]. Most exhaust manifold pipes are made of cast iron. For instance, design and solidification simulation of exhaust manifold made of silicon molybdenum ductile iron [66]. The researchers reported that the trial cast consists of $78 \%$ nodularity, with $10 \%$ pearlite and a maximum of $5 \%$ carbide. The mechanical properties had tensile strength of $527 \mathrm{MPa}$, elongation $14 \%$ and hardness of about 215 BHN. Some researchers [67] conducted exhaust manifold simulation analysis for vehicular diesel engine. The researchers concluded that the obtained exhaust manifold temperature of $687^{\circ} \mathrm{C}$ is lower than the alloyed material microstructural transformation at $835^{\circ} \mathrm{C}$. There are thermal insulations in practice to reduce heat from the exhaust manifold of DEL and to minimize thermal losses and failures with use of exhaust manifold gaskets [68].

\subsection{PARAMETERS OF LOCOMOTIVE ENGINES}

\subsection{Engine Models and Classes of Diesel Electric Locomotives}

Engine model (EM) indicates the manufacturer, specifications and identification number of the LE classified with both alphabetic and numerical codes. EM is important when a request is necessary for parts replacement, refurbishment, maintenance as well as in procurement of a new LE. It was observed that the LE imported into Nigeria were predominantly from brand names like: Cummins, Diesel locomotive works (DLW) from (USA), General Motors (Electro motive divisionEMD) and General Electric rail LE except those imported in 1998 and 2019 that were from China. The purchases of similar models were intended to enhance standardization in exchange of parts during maintenance. The benefit of interchangeability in maintenance practice, allows cannibalization of one LE model part to repair another similar LE model; in difficult circumstances, particularly when a spare part is out of stock. This practice will greatly reduce LE down time. The reported gross insufficient LE can be alleviated from similar engine models. On the other hand, the classes of LE are identification number provided by the fleet owners for easy deployment and to track maintenance history. It should be noted that in NRC, each $\mathrm{LE}$ is given name of prominent towns, rivers or personality, which is a practice similar to Egypt, South Africa and India railways [69]. LE class is useful in scheduling maintenance and system replacement based on operations, installation capacity and age. For instance, the decision for full or partial refurbishment and retirement of LE are enhanced with knowledge of the locomotive classes, apart from actual maintenance history.

\subsection{Nominal Powers of Diesel Electric Locomotives} Locomotive engine power (LEP) refers to the power measured during load box test or at the flywheel of a rail car using dynamometer at the engine load test bench [70]. The actual mechanical power output of the engine is termed the locomotive brake power (LBP), which is the power available to the traction motors and the wheels. LBP is always less than LEP due to friction losses inside the engine as well as energy absorbed by turbocharger, water pump and compressor. The LNP of LE is the lowest measure of work done with available potential to carry payload, overcome gradient and aerodynamic forces. LNP is a necessary parameter of LE for her deployment in terms of capacity and routes. The average current LNP of $\mathrm{LE}$ in NRC ranges from $500 \mathrm{~kW}$ to $2448 \mathrm{~kW}$ (See Figure.1). The LE imported for NRC are shown in Figure 1.

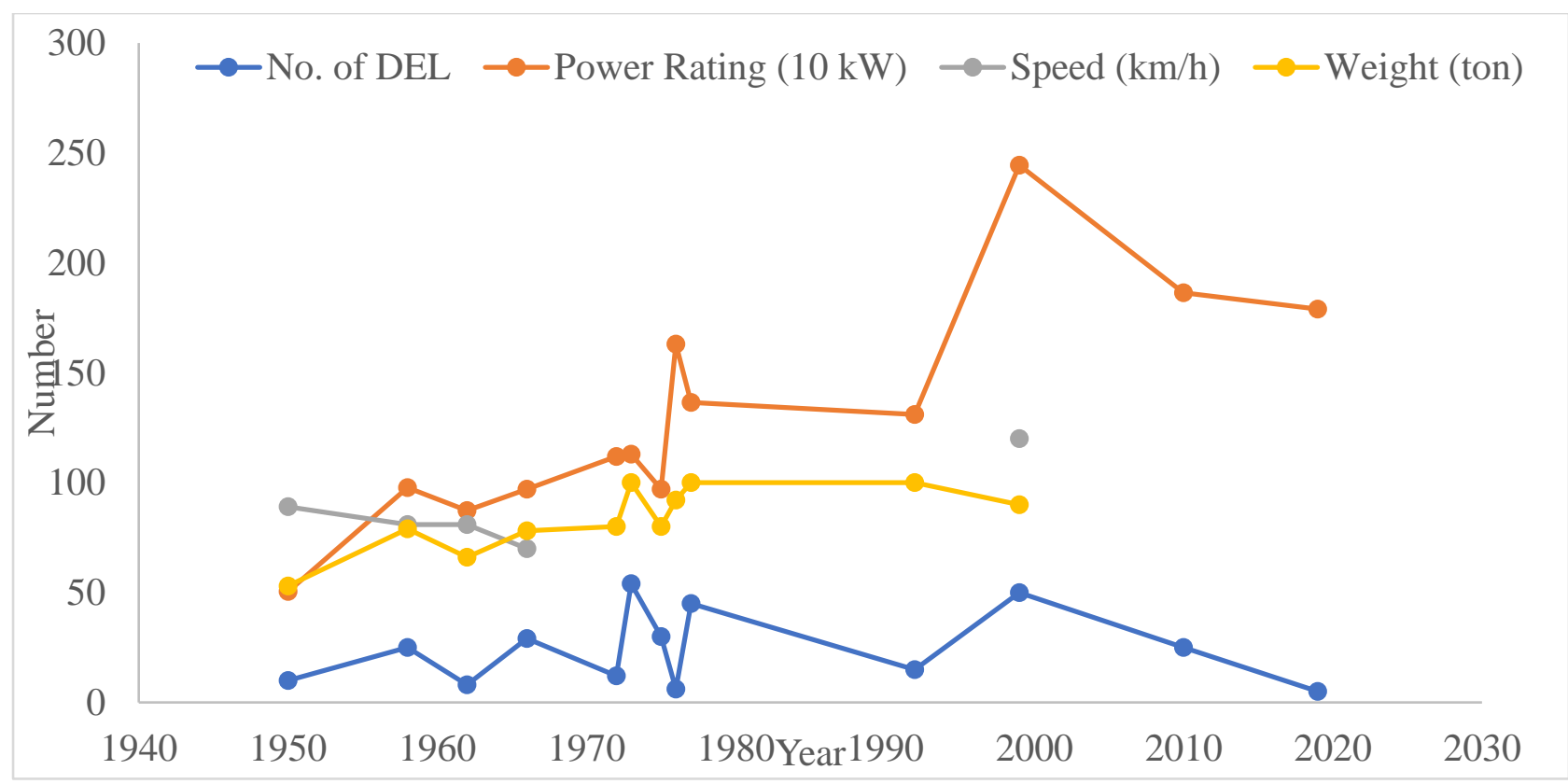

Figure 1: The acquisition of diesel electric locomotives with its characteristics in NRC. 
LBP is always less than LEP due to friction losses inside the engine as well as energy absorbed by turbocharger, water pump and compressor. The LNP of LE is the lowest measure of work done with available potential to carry payload, overcome gradient and aerodynamic forces. LNP is a necessary parameter of LE for her deployment in terms of capacity and routes. The average current LNP of LE in NRC ranges from $500 \mathrm{~kW}$ to $2448 \mathrm{~kW}$ (See Figure1). The LE imported for NRC are shown in Figure 1.

\subsection{Number of Cylinders in Diesel Engine of DEL}

Locomotive engine can be classified by Veetype cylinder arrangement and numbers of cylinders such as 8, 12 and 16. For example, eight-cylinder LE will have 8 intake and exhaust valves which necessitates 16 cams on shaft. Similarly, 12-cylinders locomotive engine will have proportionate valves, and cams. The number of cylinders in LE is partly related to the power output of the engine and hence fuel consumption. Other factors include engine speed and efficiency of the fuel supply mechanism. Power cylinder assembly consists of cylinder liner, piston, rings, connecting rods and bearings [56].

It should be noted that the greatest wear on cylinder takes place at the top due to piston rings travels and pressure from burning fuels which causes cylinder to taper and ridge, hence the need for measuring cylinder diameter during major scheduled maintenance. NRC have DEL of 8 and 12 cylinders and similar to railways in selected countries (see Table 1).

Table 1. Parameters of locomotive engines in NRC

\begin{tabular}{|c|c|c|c|c|c|c|c|c|c|c|}
\hline $\begin{array}{l}\mathrm{S} / \\
\mathrm{N}\end{array}$ & Engine parameter & $\begin{array}{l}1126 \\
\text { class }\end{array}$ & $\begin{array}{l}1701 \\
\text { class }\end{array}$ & $\begin{array}{l}1801 \\
\text { class }\end{array}$ & $\begin{array}{l}1807 \\
\text { class }\end{array}$ & $\begin{array}{l}1901 \\
\text { class }\end{array}$ & $\begin{array}{l}2001 \\
\text { class }\end{array}$ & $\begin{array}{l}2100 \\
\text { class }\end{array}$ & $\begin{array}{l}2200 \\
\text { class }\end{array}$ & DMU class \\
\hline 1 & Year of Acquired & 1977 & 1972 & 1976 & 1977 & 1991 & 1992 & 1998 & 2010 & 2019 \\
\hline 2 & Engine Model & $\begin{array}{l}\text { EMD1 } \\
2-645 E\end{array}$ & $\begin{array}{l}\text { ALCO8. } \\
251 \mathrm{E}\end{array}$ & $\begin{array}{l}\text { 7FDL12 } \\
\text { GE }\end{array}$ & $\begin{array}{l}\text { 7FDL8 } \\
\text { GE }\end{array}$ & $\begin{array}{l}\text { EMD12 } \\
645 \mathrm{E} 3 \mathrm{~B}\end{array}$ & $\begin{array}{l}\text { EMD12 } \\
645 \mathrm{E} 3 \mathrm{~B}\end{array}$ & $\begin{array}{l}12 \mathrm{~V} 240 \\
\mathrm{ZD}\end{array}$ & $\begin{array}{l}\text { 7FDL12 } \\
\text { EFI GE }\end{array}$ & $\begin{array}{l}\text { Cummins } \\
\text { 6BTA5.9- } \\
\text { G3 }\end{array}$ \\
\hline 3 & $\mathrm{LNP}[\mathrm{kW}]$ & 1119 & 1119 & 1641 & 1357 & 1305 & 1305 & 2237 & 1864 & 895/Engine \\
\hline 4 & Nos of cylinders & 12 & 8 & 12 & 8 & 12 & 12 & 12 & 12 & 12 \\
\hline 6 & stroke $(\mathrm{S})$ & 254.0 & 267 & 266.7 & 266.7 & 254 & 254 & 275 & 266.7 & 165.1 \\
\hline 7 & Stroke ratio(B/S) & 0.91 & 0.86 & 0.86 & 0.86 & 0.91 & 1.6 & 0.87 & 0.85 & 0.85 \\
\hline 8 & Compression ratio & $14.5: 1$ & $11.5: 1$ & $12.7: 1$ & $12.7: 1$ & $14.5: 1$ & $14.5: 1$ & $12.4: 1$ & $15.7: 1$ & $15.5: 1$ \\
\hline 9 & $\begin{array}{l}\text { Displacement per } \\
\text { cylinder }\left(\mathrm{cm}^{3}\right)\end{array}$ & 10.6 & 10.9 & & 10.7 & 10.6 & 10.6 & 12.44 & & 5.88 \\
\hline 10 & $\begin{array}{l}\text { Engine low speed } \\
(\mathrm{rpm})\end{array}$ & 200 & 400 & 400 & 400 & 255 & 255 & 450 & 385 & 600 \\
\hline 13 & $\begin{array}{l}\text { Engine Operating } \\
\text { principle }\end{array}$ & $\begin{array}{l}2 \\
\text { Strokes }\end{array}$ & $\begin{array}{l}4 \\
\text { Strokes }\end{array}$ & $\begin{array}{l}4 \\
\text { Strokes }\end{array}$ & $\begin{array}{l}4 \\
\text { Strokes }\end{array}$ & $\begin{array}{l}2 \\
\text { Strokes }\end{array}$ & $\begin{array}{l}2 \\
\text { Strokes }\end{array}$ & $\begin{array}{l}\text { 2- } \\
\text { strokes }\end{array}$ & $\begin{array}{l}\text { 4- } \\
\text { strokes }\end{array}$ & 4-strokes \\
\hline 14 & $\begin{array}{l}\text { Cylinder } \\
\text { arrangement }\end{array}$ & $45^{0} \mathrm{~V}$ & $50^{\circ} \mathrm{V}$ & $45^{0} \mathrm{~V}$ & $45^{0} \mathrm{~V}$ & $45^{0} \mathrm{~V}$ & $45^{0} \mathrm{~V}$ & $50^{\circ} \mathrm{V}$ & $45^{0} \mathrm{~V}$ & $50^{\circ} \mathrm{V}$ \\
\hline
\end{tabular}

The 8 cylinders NRC DEL in Table 1, are in the eastern line that serves Port-Harcourt,

Enugu, Kafanchan, Jos, up to Maiduguri; while the 12cylinders DEL (Table 1) serve western and central lines as well as inter city services in Lagos. It also extends up to Kano and serves Warri to Itakpe and Abuja to Kaduna. The 12-cylinders DEL are more powerful and better equipped to carry heavier loads but consumes more fuel than 8-cylinders due to her weight [72]. However, factors that makes DEL to attain lowest fuel consumption depends on the vehicle weight, low wheel rolling resistance, well maintained injectors and driving habits among several factors.

\subsection{Cylinder Bore and Piston Stroke}

The ratio of bore and stroke is called square ratio, which is obtained by dividing the bore by the stroke. The ratio may be under square, square or over square but depended on preference for power at high engine speeds (rpm) (over square) or high torque at lower engine speeds (under square) and affects engine efficiency. Some researchers [73] applied the varied bore to stroke ratios to investigate fuel injection engine fueled with ethanol blended gasoline. The researchers reported that over square engine had higher compression ratio, higher pressure, faster combustion rate due to its larger flame surface area and larger turbulence intensity than under 
square engine. Similarly, some researchers [73] investigated the effect of bore/stroke ratio on a single cylinder two stroke opposed piston engine. The researchers reported heat losses decrease with increasing square ratio, which resulted in improved mechanical efficiency with reduced specific fuel consumption (SFC). For port-operated cylinders, the efficiency also depends on the in-flow velocity and ports opening and closing timings [74]. In Table 1, the DEL of NRC were generally under square that ranges from 0.85 to 0.91 except General motors locomotive engines with model EMD12645E3B, with stroke ratio of 1.6, which is an over square engine. Therefore, stroke ratio is a relevant factor in design, deployment and maintenance of locomotive engines.

\subsection{Compression Ratio}

The compression ratio is the ratio of total volume of combustion chamber when the piston is at the bottom dead centre with respect to its minimum volume and when the piston is at the top dead centre. Therefore, compression ratio is a measure of compressed charge to uncompressed charge and it shows how tightly the incylinder contents are thermodynamically conditioned to facilitate combustion process and hence power output [75]. A researcher [76] reported that diesel engines have compression ratios, which range between 12:1 and 24:1. The higher compression ratios of diesel engines provide results to higher pressure and thermal efficiencies of up to $45 \%$.

During DEL cruise at low power, the notch can be selected to operate at very high compression ratios to keep efficiency high. Therefore, compression ratio of DEL is an important control parameter, which depends on the user, ambient temperature, cylinder peak pressure, and type of fuel [77, 78]. In Table 1, the compression ratios of DEL in NRC ranges between 11.5 to 15.7 but recently acquired locomotive engines had 15.5 and 15.7 , to attain lowest specific fuel consumption (SFC). The Lowest SFC occurs at minimal amount of air required to oxidize fuel and generate heat to maintain combustion process at equivalence ratio close one but not above $[79,80]$.

\subsection{Displacement per Cylinder}

A researcher [72], reported displacement per cylinder of $10.96 \mathrm{~cm}^{3}, 10.95 \mathrm{~cm}^{3}$ and $11.6 \mathrm{~cm}^{3}$ for wide guage, diesel and mixed train (WDM) and wide guage diesel goods train (WDG) DEL, respectively, of Indian Railways. Similarly, in Table 1, the displacement per cylinder of DEL in NRC, range between $10.6 \mathrm{~cm}^{3}$ to 12.44 $\mathrm{cm}^{3}$ except DMU class that had $5.88 \mathrm{~cm}^{3}$, use for passenger and cargo trains that can travel for over 1000 $\mathrm{km}$ trip with high gradient and curves. The DMU with displacement per cylinder of $5.88 \mathrm{~m}^{3}$, is mainly for intercity of about $186 \mathrm{~km}$ between Abuja and Kaduna, in Nigeria. The DEL performance and SFC can best be evaluated at the same displacement at its operating conditions [80]. The researcher concluded that higher displacement leads to higher power output per cylinder.

\subsection{Locomotive Engine Low, Idle and Full Speeds}

A researcher [70] describe the starting of DEL to begin with activation of low speed lever. Then idle speed lever is subsequently activated and runs for a reasonable time before engagement of notch one. From notch 1 up to the highest notch, the DEL operates at diesel engine full speed. The DLW built locomotive engine of 16 cylinders (ALCo 251C (WDG) by Indian Railways, had idle and full speed of $350 \mathrm{rpm}$ and 1, $050 \mathrm{rpm}$, respectively, which were key factors in design [70]. Some researchers [80] reported an improvement of diesel locomotive engine efficiency and reliability as a result of power unit load control system modernization at idle and full speed of 500 and $1000 \mathrm{rpm}$ respectively. Low engine speed results in low noise and reduced fuel consumption while low idle speed ensures lean fuel consumption during idling [5]. The various diesel locomotive engines of NRC have different engine low, idle and full speeds as shown in Table 1 .

\subsection{Cylinder Arrangement}

Some researchers $[82,83]$ described Vee-engine cylinder arrangement as most common for an internal combustion engine including diesel locomotive engine. In Table 1, all the DEL of Nigerian railways have Vee cylinder arrangement at $45^{\circ}$ and $50^{\circ}$.

\section{8. $\quad$ Locomotive Engine Application Principles}

Four-stroke engine works as naturally aspirated or with turbocharger and require two rotations made possible by camshaft geared at half the speed of the crankshaft. In Table 1, NRC has 2-stroke and 4-stroke cycles LE. The 2-stroke is cheaper and more fuel efficient than 4-stroke LE. The 2-stroke cycle diesel LE found application in passenger locomotives on account of her lower starting effort and operates at high speeds to maintain passenger schedules. The 4-stroke cycle diesel LEs found application in freight with cargo due to her high starting tractive and sustained energy, necessary to move heavy trains but at relatively reduced maximum speeds. Four stroke has better efficiency than two stroke engines while two stroke engines are easier to crank and to start [5].

\subsection{THE FUTURE OF RAILWAY AUTOMOTIVE POWER}

\subsection{Reliability of Diesel Electric Locomotives}

Some researchers $[83,84]$ studied reliability of DEL. Their recommendations include maintenance to be scheduled 3 hours from departure point with use of quality products for reliable service $[84,85]$. The researchers also suggested proper analysis to eliminate minor failure permanently as well as placing maintenance staff at the 
highest locomotive engine failing locations. However, DMU has advantage to continue on its journey, but with reduced speed to get to her destination, when one engine fails. The frequency of failed DEL, can be reduced with mean time to repair (MTTR), if instituted for the passengers and freight trains. LE lifespan is about 30-35 years but depends on the maintenance regime and utilization. Some researchers [84, 85] recommends reliability, availability and maintainability study, to take informed decision for retirement of LE, full refurbishment and partial refurbishment as well as acquisition and deployment of LE can be guided by matrix selection factors. In the selection matrix, mechanical system represents defects associated with compressor, fans, pumps, hydraulic, and pneumatic control systems. The electric/fuel system failure includes faults in fuel lines, nozzle, relays, switches, electronic governor and fuel economy of the DEL. The NRC EMD 126456EB LEs are favoured for cargo due to its high torque and her superiority with 7.15 index. The matrix factors and their degree of severity in effective maintenance of DEL are as shown in Table 2.

Table 2. Matrix selection factors for locomotive engines

\begin{tabular}{|c|c|c|c|c|c|c|c|c|c|c|}
\hline \multirow[t]{2}{*}{$\begin{array}{l}\mathbf{S} / \\
\mathbf{N}\end{array}$} & \multirow[t]{2}{*}{ 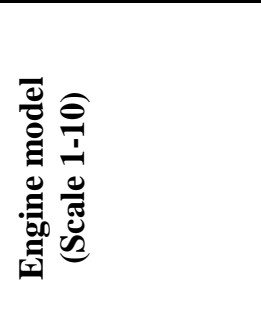 } & \multirow[t]{2}{*}{ 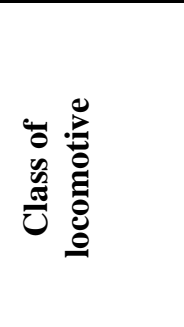 } & 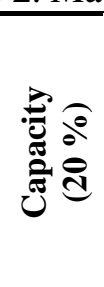 & 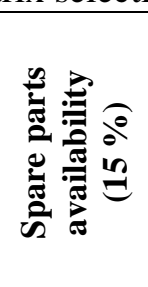 & 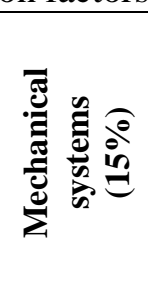 & 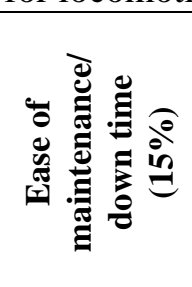 & 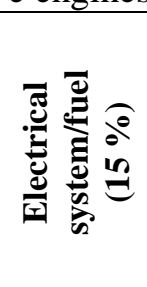 & 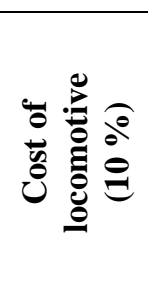 & 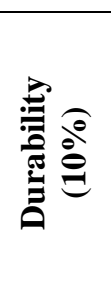 & \multirow[t]{2}{*}{ 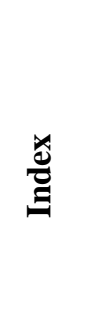 } \\
\hline & & & 0.2 & 0.15 & 0.15 & 0.15 & 0.15 & 0.1 & 0.1 & \\
\hline 1 & EMD12-645E & 1126 class & 4 & 4 & 6 & 5 & 7 & 4 & 5 & 5.00 \\
\hline 2 & ALCO8.251E & 1701 class & 4 & 4 & 6 & 5 & 7 & 4 & 6 & 5.10 \\
\hline 3 & 7FDL12 GE & 1801 class & 7 & 5 & 6 & 6 & 7 & 5 & 6 & 6.10 \\
\hline 4 & 7FDL8 GE & 1807 class & 6 & 5 & 6 & 7 & 7 & 4 & 6 & 5.95 \\
\hline 5 & EMD12645E3B & 1901 class & 5 & 6 & 9 & 8 & 8 & 6 & 8 & 7.05 \\
\hline 6 & EMD12 645E3B & 2001 class & 5 & 6 & 9 & 8 & 8 & 7 & 8 & 7.15 \\
\hline 7 & 12V240ZD & 2100 class & 9 & 8 & 5 & 5 & 6 & 8 & 5 & 6.70 \\
\hline 8 & 7FDL12EFI GE & 2200 class & 8 & 8 & 5 & 5 & 6 & 8 & 5 & 6.50 \\
\hline 9 & 7FDL12EFI GE & 2300 class & 8 & 8 & 5 & 5 & 6 & 8 & 5 & 6.50 \\
\hline 10 & $\begin{array}{l}\text { Cummins } \\
\text { 6BTA5.9-G3 }\end{array}$ & DMU class & 8 & 9 & 5 & 4 & 6 & 9 & 4 & 6.50 \\
\hline
\end{tabular}

\subsection{Improvement of Power Output and Emission Reductions in DEL}

Indian railway was reported to have improved the power output of EMD locomotive engine from $3000 \mathrm{~kW}$ to $3371 \mathrm{~kW}$ by increasing engine rpm from 904 to 950 rpm, increased fuel delivery and prevention of undue vibrations of engine [5]. NRC and rail firms in Africa should benefit from similar researches on how to increase the power out of the current DMU from about $900 \mathrm{~kW}$ to $1000 \mathrm{~kW}$, in their fleet to meet teeming passenger and freight traffics [86]. Some researchers [87] reported the development and implementation of an electronic fuel injection system for a 4-stroke DEL of Indian Railways. The plunger diameter of fuel injection pump was increased from diameter $15 \mathrm{~mm}$ to diameter $17 \mathrm{~mm}$ and resulted in increased peak fuel line pressure from 750 to 1000 bars. The overall benefits include replacement of mechanical fuel injection with electronic fuel injection, reduction of black smoke and elimination of hot engine failures of the locomotives [87].

\subsection{Renewable Fuels for Diesel Electric Locomotives}

Worldwide, emissions from combustion of coal and diesel fuels in DEL and thermal power plant have come under scrutiny, except retrofitted with fluidized bed thermal power generator and dedicated fan $[88,89]$. Germany will reach her target of $100 \%$ renewable fuels fired locomotive in 2038, far ahead of its original goal of 2050 based on the evaluation of by some researchers [90]. India railway was reported to have commence implementation in the use of biodiesel blends on her DEL [91]. Methanol produced from coal and other waste resources into liquid fuel was found particularly useful for traction purpose in DEL [91]. Among the other renewable fuels in the blended form for DEL are biodiesel, 
bioethanol, and bio-methanol [92, 93]. However, the demerits are deterioration of the biodiesel and corrosion effects on the copper and brass parts of DEL [91].

\subsection{Potentials for Development of Gas Turbine Electric Locomotives}

Nigeria has enormous gas reserve in excess of 185 trillion cubic feet and expected to last for over 50 years [94]. Nigeria gas pipelines transmission network has reached many locations. Similarly, NRC has planned to extend her standard guage railroad to Kano and Niger Republic. The gas pipeline can be source of gas fuel to power DEL. The recent commencement of conversion of petrol car into gas-fired car, should continue until gasfired railcar is attained and LE are converted into gas-fired LE. NRC and GRC can explore the use of natural gas in liquid form (LNG) and in a compressed gas form (CNG) as alternative to diesel fuel for her LE. Area of research for NRC to power her motive power is the use of LNG or LPG in a gas turbine-EL.

\subsection{Potentials for Development of Electric Locomotives}

Electricity supply and railway lines will have to be in one route to maximize the economies of right of way and business competitiveness due to the initial investment for full-fledged electrified network for electric trains [95]. The principal challenges that need harmonization in deployment of EL are the capacity of the electrical substations during peak demands and the electrical interconnection infrastructures between the mains grid and the railway locomotive systems [95]. Therefore, national planning will have to incorporate the above in her policies to attain seamless developments in all the sectors. The establishment of electric power stations by national grid can be for injection of additional electric power for locomotive trains via overhead or underlay $[96,97]$.

Battery-powered electric vehicles in NRC and the recent battery-powered electric tricycles and vehicles at Abakaliki, Nigeria, can kick-start reverse engineering towards battery-powered electric railcars. The domestication of EL manufacturing with focused on energy efficient technologies at speed of $50-55 \mathrm{~km} / \mathrm{h}$ and loading capacity of 789-872 tons in turkey [97].

\subsection{Diesel Hydraulic Locomotives}

According to some researchers $[98,99]$ in diesel hydraulic locomotive (DHL), the diesel engine transmits its power to the wheels by hydraulic torque converter. The torque converter has gear ratios but gear box between the diesel engine and the torque converter. The three main parts of the torque converter are impeller connected to the diesel engine, driven wheel coupled to the axle and guide wheel placed between the impeller and axle. The merits include its lighter weight for same power output DEL and smooth operations but requires more frequent repairs.
Some researcher [98] utilized two DHL to compare pollutions emissions with European standards in the city of Timisoara, Romania. The researchers [99] concluded that nitrogen dioxide $\left(\mathrm{NO}_{2}\right)$ emission for $920 \mathrm{~kW}$ and $1000 \mathrm{~kW}$ DHL range from 110-856 ppm and 410-1011 $\mathrm{ppm}$, respectively. They recommended selective noncatalytic reduction technique to reduce $\mathrm{NO}_{2}$, after flue gas temperature studies emission from the DHL.

\subsection{Fuel Cell Locomotives}

Some researchers $[100,101]$ reviewed fuel cell technology with emphasis on the material composition, current challenges and advantages in its application in automotive and electricity generation. Fuel cell converts chemical energy to electricity. The researchers concluded that fuel cell technology process converts chemical energy to electricity, which is clean and renewable energy source. A researcher [101] reported that the first fuel cell rail locomotive was demonstrated in 2002, in US and five of the fuel cell locomotives were used in mines, switching operations in railway station and in light line haul work in South Africa in 2012. The researchers [101] reported energy consumption reduction of diesel hybrid with fuel cell locomotive to be about $12 \%$ and hydrogen fuel cell locomotive to be about $28 \%$.

\subsection{CONCLUSION}

The review of locomotive engines and the future of railway automotive power in Africa, was undertaken with Egypt, Ghana, Kenya, Nigeria, South Africa and Zambia railway systems in perspective. The conclusions drawn include low train density in the selected countries except South Africa. The production of component parts of locomotive engines can be carried out with additive manufacturing, 3D printing, ductile cast iron and dieforging using materials such as steel alloys and aluminum alloys to address inadequate spare parts and improve LE down time. The procurement, selection and maintenance of locomotive engines can be guided by the engine parameters as well as the selection matrix factors. For example, NRC EMD 126456EB LE are favoured for cargo due to its high torque and her superiority with 7.15 index, using the matrix selection factors. African railway firms such as ENR, GRC, RVR, NRC, SAR, TFR and RSZ need to increase her fleets and capacities of her mainline locomotives for passenger and cargo trains from about 1000-3500 kW. Railways' research and collaborative efforts in Africa, should focus on increased reliability, increased engine power output, renewable energy sources, gas usage and railway electrification.

\section{ACKNOWLEDGMENTS}

The first two authors appreciate the opportunity to work in the Nigerian Railway Corporation (NRC) at various capacities. The authors also appreciate the technical experiences that comes with their association 
with NRC.

\section{DISCLAIMER}

The views and opinions expressed in this manuscript do not necessarily reflect those of NRC or any other companies around the world. The authors make no representations or warranties with respect to the accuracy or completeness of the contents of this manuscript. The authors shall not be liable for any loss of profit or commercial damages, including but not limited to special, incidental or consequential damages. However, any error or misinformation are regrettable but some of the opinions expressed reflect the array of acknowledged references.

\section{REFERENCES}

[1] Ozigis, I.I. and H. Dandakuota, 'Conceptual coal fuel supply to coal-fired thermal power plant'. Journal of the Nigerian Institution of Mechanical Engineers, 2 (1), (2010),47.

[2] Bullock, R. 'Off-track: Sub-Sahara African railways, background paper 17, Africa infrastructures country diagnostic", Africa's Railways, (2009),8-88.

[3] Al-Tony, F.E. and Lashine, A. "Cost-benefit analysis of railway electrification: case study for Cairo-Alexandria railway line', Impact Assessment and Project Appraisal, (2000), 323-332.

[4] Transport, National reporting to CSD $18 / 19$ by Switzerland, 1-13.

[5] Mane, D.S. "'Technologies adopted in diesel locomotive engine over Indian railways', IOSR Journal of Mechanical and Civil Engineering, (2017), 01-05.

[6] Doomernik, J. E. "Performance and efficiency of high-speed rail systems", Transportation Research Procedia, Elsevier, 8, (2015), 136-144.

[7] Stoilova, S., Munier, N., Kendra, M. and Skrúcaný, T. "Multi-criteria evaluation of railway network performance in countries of the TEN-T orient-east med corridor", Sustainability, 12, (1482), (2020), 122.

[8] Mckinnon, A. "Performance measurement in freight transport, its contribution to the design implementation and monitory of public policy", Logistics Development Strategies and Performance Measurement, 45, (2015), 1-7, Queretaro, Germany.

[9] Peetawan, W. and Suthiwartnarueput, K. "Identifying factors affecting the success of rail development projects contributing to a logistics platform: A Thailand case study", Kasetsart Journal of Social Sciences, (2018), 320-327.

[10] Ayoola, T. A. "Establishment of the Nigeria railway corporation", Journal of Retracing Africa, 3910, (2016), 21-42.

[11] Nigerian Railway Corporation, Ebute-Metta, Lagos, facts and figures, (2006), 1-30.

[12] Oyefuga, B. and Egbetokun, A. "Rebuilding rail infrastructure in Nigeria: policy problems and prospects", Proceedings of the KSR Conference.
The Korean Society for Railway, (2007), 18831895.

[13] Igwe, C.N., Oyelola, O.T., Ajiboshin, I.O. and Raheem, S. “A Review: Nigerian's transportation system and the place of entrepreneurs", Journal of Sustainable Development Studies, 2(2), (2013), 168-180.

[14] Abioye, O. "Privatization of the Nigerian railway corporation: An evaluation of critical choices", Thesis Submitted to Cardiff Metropolitan University in Partial Fulfillment of the Requirements for the Degree of Doctor of Philosophy, London School of Commerce, (2016), 24-25.

[15] National Bureau of Statistics, Rail transportation data, (2019), 1-9.

[16] Akwetteh, L.N., Xu, C., Putri, M.D.P.W. and Okoe, L.N. "The Current Railway Development and Its Influencing Factors in Ghana." Open Journal of Social Sciences, 9(3), (2021), 228-244.

[17] Railway Master Plan of Ghana Final Report, "Ghana railway development authority of the ministry of transport, provision of engineering consultancy services", (2013).

[18] Sugimoto, M. "Procurement of locomotives, rolling stock and workshop", (2006), 1-18.

[19] Business Consulting.Ghana, Overview study, railway sector in Ghana, 1-9.

[20] Mathabatha, D. M. S. "Rail transport and the economic competitiveness of South Africa, timeous delivery of goods and demurrage", MiniDissertation Submitted in Partial Fulfillment of the Requirements for the Degree of Master of Business Administration at Potchefstroom Campus of the Northwest University, South Africa, (2015).

[21] Wei, C. "Study on planning scheme of Egypt national railway network", $6^{\text {th }}$ International Conference on Energy and Environmental Protection, Advances in Engineering Research, 143, (2017), 236-240.

[22] Rail infrastructure in Egypt, Future Rail and Metro, (2016),1-5.

[23] Githaija, N. M. "The successes and challenges of Kenya's Mombasa-Nairobi standard guage railway transport operations; A special reference to the users". Research in World Economy, 12(2), (2021), 258-271.

[24] Kabaale, P. "Rift valley railway projects", Rift Valley Railway (Kenya) Ltd, (2011), 1-15

[25] Otwori, J. L. Fredrick, A. G. Abduletif, A. A. and David, L. D. "Kenya's standard guage project in the context of theory and practice of regional planning", ACTA Caolus Robertus, 10(2), (2020), 85-96.

[26] Kenya railways, Africa gearing up, $P W C$, (2012),49. 
[27] Taylor, I. "Kenya's new lunatic express: the standard guage railway", African's Studies Quarterly, 19(3-4), (2020),29-52.

[28] Kasoma, A. and Zulu, D. B. "Analysis of Zambia railway sector-structural deficiencies and the way forward", (2019),1-33.

[29] Sharma, S. K. and Kumar, A. "A comparative study of Indian and world railways", International Journal of Mechanical Engineering and Robotics Research, 1(1), (2014),114-120.

[30] Blumenfeld, M. Wemakor, W. Azzouz, L. and Roberts, C. "Developing a new technical strategy for rail infrastructure in low -income countries in sub-Saharan Africa and South Asia", Sustainability, 11(4319), (2019), 1-23.

[31] Railway Reform: Toolkit for improving rail sector performance: case study: Indian railways, The World Bank, (2017), 426-444.

[32] Agarwal, A. K. "Railway locomotive: status, challenges and opportunities in India", Indian Institute of Technology Kanpur, (2019).

[33] Nigerian railway corporation, (2020).

[34] Odeleye, J. A. "Public-private participation to rescue railway development in Nigeria”. Japan Railway and Transport Review, 23, (2000),41-49.

[35] Filho, D. D. S. “An appraisal of the engine cylinder block materials", SAE International, (2013),1-9.

[36] Ansari, M. D. Haque, M. F. and Joshi, S. "Design and analysis of engine block", International Research Journal of Engineering and Technology, 7(5), (2020), 3514-3620.

[37] European aluminum association, the aluminum automotive manuals, applications: power trainengine block, piston and cylinder heads, auto@eaa.be, (2011), 1-23.

[38] Torres, R. Esparza, J. Velasco, E. Garcia-Luna, S. and Colas, R. "Characterization of an aluminum engine block", International Journal of Microstructure and Materials Properties, 1(2), (2006), 129-138.

[39] Solanki, A., Tamboli, K. and Zinjuwadia, M.J. "Crankshaft design and optimization: a review", National Conference on Recent Trends in Engineering and Technologies, (2011), 1-8

[40] Kubo, H. and Mori, H. "Technical developments and recent trends in crankshafts materials", Kobelco Technology Review, 26, (2005), 37-42.

[41] Stojanovic, B. and Glisovic, J. "Automotive engine materials, material science and materials engineering", Science Direct, (2016).

[42] Gupta, S. N., Mahesh, N. and Kumar, D. B. "Design and analysis of crankshaft used in aerospace applications and comparison using Different materials", International Journal of Engineering research, 4(9), (2015),79-486.

[43] Pawar, P. P., Dalvi, S. A., Rane, S. and Divakaran, C. B. "Evaluation of crankshaft manufacturing methods-an overview of material removal and additive processes", 2(4), (2015),118-121.
[44] Ktari, A. Haddari, N. and Ayedi, H. F. Fatigue fracture expertise of a train crankshaft', $5^{\text {th }}$ International Conference on Advances in Mechanical Engineering and Mechanics, Hammamet, Tunisia, (2010), 1-6.

[45] Vencl, A. and Rac, A. "Diesel engine crankshaft journal bearing failures: A case Study". Engineering Failure analysis, 44, (2014), 217-228.

[46] Kraymico, A. and Kraymlen, P. "Properties of the bearing alloys used for slide bearings of crank mechanism", Journal of Kones Internal Combustion Engines, 11(1-2), (2004), 393-398.

[47] Ozigis, S. O. and Aliyu, A. B. "Analyses of cast aluminium tin copper alloy as bearing materials", Journal of the Nigerian Institution of Mechanical Engineers, 7(1), (2017), 95-104.

[48] Shao, K., Liu, C. W., Bi, F. R., Lu, D. and Zhang, J. "Analysis of hydrodynamic loads on performance characteristics of engine main bearings", Proceedings of Institution of Mechanical Engineers, Part J., Journal of Engineering Tribology, 229(6), (2015), 667-676.

[49] Tiwari, S. and Kaviti, K. A. "Parameters influencing connecting rod: a review". International Journal of Scientific and Engineering Research, 6(8), (2015), 8-17

[50] Sriharha, B. and Rai, S. P. "Design considerations for connecting rods", International Journal of Engineering and advanced Technology, 9(3), (2020), 2368-2373.

[51] Fuertes, J. P., Luis, C. J., Luri, R., Salcedo, D. Leon, J. and Puertas, I. "Design, simulation and manufacturing of a connecting rod from ultra-finegrained material and isothermal forging", http:/creativecommons.org/licenses/By-NC-

ND/40/ (2015), 1-24.

[52] Singh, A. R. and Sharma, K. P., "Design, analysis and optimization of three aluminum piston alloys using FEA", International Journal of Engineering Research and Applications, 4(1), (2014), 94-102.

[53] Dhamecha, Y. Saptarshi, V. Parikh, S. and Parnami, T. "Design and analysis of piston using different materials", International Research Journal of Engineering and Technology, 7(12), (2020), 11121117.

[54] Dolan, R., Budde, R. and Chramm, S. "3D printed piston for heavy -duty diesel engines", 2018 NDIA Ground Vehicle Systems Engineering and Technology Symposium, Power and Mobility Technical Session, August 7-9, 2018, Novi, Michigan, 2-8.

[55] Kim, D., Ito, A., Ishikawa, Y., Osawa, K. and Iwasaki, Y. "Friction characteristics of steel pistons for diesel engines", Journal of Materials Research and Technology,1(2), (2012), 98.

[56] Vukicevic, M. Racic, N. and Ivosevic, S. "Piston ring material in a two-stroke engine which sustains wear due to catalyst fines", Ship Building, 70(2), (2019) 155-169. 
[57] Senator, A. and Aleksendria, D. "Advances in piston rings modelling and design", Recent Patents in Engineering, 7, (2013), 61-67.

[58] Symytka, F., Osmond, P., Pemy, L., Masson, P. D. and Forre, A. "Automotive cylinder heads: recent advances on thermal-mechanical fatigue design and upcoming challenges", Matec Web of Conferences, Fatigue, 165(17003), 2018.

[59] Sabri, M. S. "Design and development of cylinder and cylinder heads of 4-stroke si engine for weight reductions", Uploaded on Research gate on 7/12/2015, (2015), 1-7.

[60] Mendes, A. S. and Cardoso, A. D. A., "Structural analysis of the aluminum cylinder head for a highspeed diesel engine", Society of Automotive Engine, 1(2562), (2007),1-10.

[61] Patil, S.D. and Mahale, D. C. "A review: rocker arm", International Journal of Advance Research Ideas and Innovations in Technology, (2019), 388371.

[62] Husaini, S. M. and Sheikh, S. "Rocker arm: a review", International Journal of Innovative Research in Science, Engineering and Technology, 2940, (2013), 1120-1126.

[63] Hendriksma, N. Kunz, T. and Greene, C. "Design and development of a 2-step rocker arm", SAE Technical Paper Series, SAE International, World Congress, Detroit, Michigan, (2017), 1-10.

[64] Mallikarjuna, V., Jashuva, N., Nagaraju, G. and Reddy, B.R.B. "Design manufacturing and cost estimation of camshaft used in two-wheeler." IOSR Journal of Mechanical and Civil Engineering, 11(1) (2014), 53-67.

[65] Gawale, S. and Shelke, S. "Diesel engine exhaust valve design and optimization." Journal of Mechanical and Civil Engineering, 13(4), (2016), 85-93.

[66] Gautam, V., Ahuja, S. and Ram, N. "Design and Solidification Simulation of Exhaust Manifold Made of SiMo Ductile Cast Iron." ELK Asia Pacific Journals (2017), 978-93.

[67] Mendes, A. S. and Tomoyose, R. "Exhaust manifold structural analysis focusing mass reduction for vehicular diesel engine application", $S A E$ International, (2010), 1-19.

[68] Nanthagopal, K., Ashok, B., Raj, R.T.K., Sabloke, H. and Agrawal, A. "Design considerations and overview of an engine exhaust manifold gasket." Journal of Chemical and Pharmaceutical Sciences, 3, (2016), 91-96.

[69] Kumar, K. "Introduction handbook on general motor diesel locomotive", Maharajpur Gwalior474020, (2006), 3-66.

[70] Gupta, S. "Load box testing of diesel locomotive Engine", MSE/MJR (Diesel)-session III, Northwestern Railway Supervisors Training Centre, AJMER, India, 84-89.

[71] Gautam, A. and Agarwal, A. K. "Comparative evaluation of turbocharger for high horsepower diesel electric locomotives", SAE International, (2013), 1-10.

[72] Agarwal, A. K. and Gautam, A. "Development of an electronic fuel injection system for a 4-stroke locomotive diesel engine of Indian railways", akagi@iitk.ac.in

[73] Jang, J. Choi, J. Yi, H. and Park, S. "Effects of the bore to stroke ratio on combustion, gaseous and particulate emission in a small port fuel injection engine fueled with ethanol blended gasoline", Energies, 13(321), (2020), 1-15.

[74] Lawal, M. N. and Muhammed, N. "Numerical study of flow velocity in the intake manifold of single cylinder port operated two-stroke spark ignition engine," Invention Journal of Research Technology in Engineering and Management, 3(5), (2019), 5968.

[75] Lawal, M. N. and Muhammed, N. "Experimental study of the influence of crankcase thermodynamics on in-cylinder delivery ratio". Invention Journal of Research Technology in Engineering and Management, 3(6), (2019), 57-71.

[76] Alqahtani, A.M., Wyszynski, M.L. and Mazuro, P. "Investigation into the effect of bore/stroke ratio on a single cylinder two stroke opposed piston engin." Journal of KONES 13(2), (2016), 8-16.

[77] Dandajeh, H.A., Sanusi, Y.S. and Ahmadu, T.O. "Exhaust emission characteristics of a gardener compression ignition engine fuelled with rapeseed methyl ester and fossil diesel." Nigerian Journal of Technology 39(3), (2020), 752-760.

[78] Mitchell, A. M. "An analysis of variable compression ratio engine". M. Eng Thesis of the University of Michigan Dearborn, USA, (2017), 4060.

[79] Ozigis, I. I. and Zarmai, M. T. "Determination of Maiganga lignite coal combustion characteristics for application in thermal power plant using standard mathematical models", Arid Zone Journal of Engineering, Technology and Environment, 15 (2), (2019), 418-434.

[80] Rymaniak, L., Daszkiewicz, P., Merkisz, J. and Bolzhelarskyi, Y.V. "Method of determining the locomotive engine specific fuel consumption based on its operating conditions." AIP Conference Proceedings, 2078 (1), (2019). AIP Publishing LLC.

[81] Babel, M. and Szkoda, M. "Diesel locomotive efficiency and reliability improvement as a result of power unit load control system modernization", Eksploatacja Niezawaodnosc- Maintenance and Reliability, 18 (1), (2016), 38-49.

[82] Georgiev, R. P. "Design of a four-cylinder internal combustion engine", M.Sc Final Project, Project and Engineering Department, UPNA, (2017), 1488.

[83] Szkoda, M. "Analysis of reliability, availability and maintainability of sm48 diesel locomotive", $22^{\text {nd }}$ 
international Symposium 3-4, June, 2014, Zilna, SK.

[84] Bose, D., Gliosli, G., Maiidal, K., Sau, S.P. and Kuuar, S. "Measurement and Evaluation of Reliability, Availability and Maintainability of a Diesel Locomotive Engine." International Journal of Scientific and Research Publications 3(9), (2013), 1-18.

[85] Hatchenko, V. "The impact of the type of operation on the parameters of a shunting diesel locomotive with hybrid power plant" MATEC Web of Conference, 133, (2017), 1-4.

[86] Gnanamoorthi, V. and Devaradjane, G. "Effects of compression ratio on the performance, combustion and emission of di diesel fueled with ethanol-diesel blend", Journal of the Energy Institute, (2015), 1926.

[87] Agarwal, A. K. and Gautam, A. "Development of an electronic fuel injection system for a 4-stroke locomotive diesel engine of Indian railways", Access on 7/10/2020, (2017), 1-33.

[88] Ozigis, I. I., Dandakouta, H. A. and Egbo, G. "Design and construction of centrifugal fan for a fluidized bed combustor". Nigerian Journal of Tropical Engineering, 8(1-2), (2015), 41-49

[89] Ozigis, I. I. "Design of fluidized bed combustor for power generation", Proceedings of the $30^{\text {th }}$ Annual General Meeting and International Conference, The Nigerian Institution of Mechanical Engineers, $24^{\text {th }}$ $27^{\text {th }}$ Oct, (2017), 28-44.

[90] García-Garre, A. and Gabaldón, A., "Analysis, evaluation and simulation of railway diesel-electric and hybrid units as distributed energy resources." Applied Sciences, 9(17), (2019), 3605.

[91] Srivastava, V. "Use of biofuels in India railways". Indian railways organization for alternative fuels, $8^{\text {th }}$ March, (2018), Delhi, India.

[92] Niculescu, R., Clenci, A. and Iorga-Siman, V. "Review on the use of diesel-biodiesel-alcohol blends in compression ignition engines." Energies 12(7), (2019), 1194.
[93] Nwakaire, J.N., Obi, O.F., Ohagwu, C.J., Anyadike, C.C., Ugwu, I.E. and Ifoh, J.U. "Engine performance of blends of palm kernel oil biodiesel under varying speed at constant torque." Nigerian Journal of Technology 39(3), (2020), 761-766.

[94] Adegbola, A.A., Ozigis, I.I. and Muhammad, I.D., "conceptual design of gas distribution pipeline network for estates in Nigeria", Nigerian Journal of Technology, 40 (1), (2021), 25-36.

[95] Frey, S. "Railway electrification systems and engineering", $1^{\text {st }}$ Edition, White Word publications, (2012), Delhi-110002, India.

[96] Lungomesha, E. and Zulu, A. "Environmental and economic benefits of railway electrification of Southern African countries", International Journal of Transport Development and Integration, 2(2), (2018), 136-145.

[97] Sertsoz, M., Fidan, M. and Kurban, M. "Most efficient use of two-types electric locomotives for load transportation". International Conference on Engineering Technologies, Dec 7-9, Kunya, Turkey, (2017), 908-911.

[98] Rasul, M.G., Patel, A., Cole, C., Sun, Y., Spiryagin, M., Godber, T. and Hames, S., "Train motive power technologies: a review on existing and emerging (hybrid) technologies". In 10th World Congress on Railway Research (WCRR2013), (2013), 25-28.

[99] Balogh, R.M., Lontis, N., Ionel, I. and Dungan, L. "Comparison study of two diesel hydraulic locomotive engines regarding the environmental pollution". Journal of Environmental Protection and Ecology, 12(4), (2011), 1840-1849.

[100] Saxena, S. and Verma, A. "Introduction to fuel cell technology: A review." International Advanced Research Journal in Science, Engineering and Technology (2015), 205-209.

[101] Hoffrichter, A. "Hydrogen-Rail (hydrail) Development." $\mathrm{H}_{2} \mathrm{O}$ Rail Workshop, Lansing, MI, (2019), 1-4. 